\title{
Problemy definicyjne w nauczaniu i badaniu khmerskiej grzeczności językowej
}

\author{
Definitional Problems \\ in Teaching and Researching \\ Khmer Language Politeness
}

\author{
Setha Long-Kucharczyk \\ INSTYTUT JĘZYKOZNAWSTWA, UNIWERSYTET IM. ADAMA MICKIEWICZA \\ AL. NIEPODLEGŁOŚCI 4, 61-874 POZNAŃ \\ sethalamu.edu.pl
}

\begin{abstract}
The author of this article refers to a set of vital definitions one has to take into consideration in teaching and reserarching language politeness. Etnolinguistic analyze of language savoir vivre is impossible vithout reference to key anthrolological notions such as culture, cultural pattern, education. The basis used in this article to reconcile various antrophological schools is the theory of Geert Hofstede who proposes wide and simple definition of culture, treated as a "collectively programmed mind" that differs one group or category of people from other. Being a Khmer naturalized in Polad, the author is fucused on pupularization of Khmer language and culture in her second motherland. Having a sense of mission to provide Polish users of Khmer language with cultural competence that will anable them to be seen in Cambodia as polite people, the author compares Polish and Khmer colloquial understanding of politeness. She also refers to Polish linguistic works on language politeness, looking for definitional solutions that will help teach and analyze language savoir vivre of the Khmers.
\end{abstract}

\section{Wstęp}

Nie będzie wielką przesadą stwierdzenie, iż ludzie zwykle pozytywnie reagują na widok obcokrajowca podejmującego się trudu mówienia ich ojczystym językiem. Może sytuacja taka nie jest czymś nadzwyczajnym dla osób pochodzących z krajów, w których językiem urzędowym jest język cieszący się statusem języka międzynarodowego, jak potocznie określa się 
języki stosowane oficjalnie przez organa ONZ, jednak w większości państw, zwłaszcza w państwach o w miarę jednolitej strukturze etnicznej, szanse przybysza na spotkanie się z życzliwym zainteresowaniem ludności miejscowej są duże. Będzie ono tym większe, im bardziej geograficznie i przede wszystkim kulturowo oddalone jest państwo, z którego pochodzi obcokrajowiec. O życzliwym zainteresowaniu nie będzie mowy, gdy mieszkańcy kraju przyjmującego pełni są uprzedzeń etnicznych lub rasowych albo zachowanie przybysza daje podstawy, by przypuszczać, iż kierują nim złe intencje. Wykluczając jednak takie skrajne sytuacje, ciekawość, jakim człowiekiem jest niezwykły, bo próbujący porozumieć się w miejscowym języku, obcokrajowiec, bywa mocną zachętą do zamienienia z nim paru zdań. To, że przybysz podejmuje się wysiłku mówienia naszym językiem jest często odbierane jako oznaka uprzejmości z jego strony.

Bez względu na to, czy chodzi o krótką rozmowę z przypadkowo spotkanym obcokrajowcem, czy o relacje wymagające częstego komunikowania się, np. relacje sąsiedzkie lub zawodowe, naturalne jest, iż każda ze stron dialogu oczekuje od drugiej szacunku. Chce, by zachowywano się wobec niej grzecznie. Pragnie również, o ile stawia sobie wysokie wymagania moralne, uchodzić za człowieka grzecznego w oczach rozmówcy.

Sprostanie tym oczekiwaniom nie jest latwe. Często nawet ludzie wychowani w tym samym kręgu kulturowym mają problem ze znajomością zasad savoir vivre'u, a cóż dopiero osoby, które muszą pokonać wiele kulturowych barier, z barierą językową włącznie. Trudno skutecznie realizować postulat grzeczności partnerom interakcji, którzy nauczeni są różnego spostrzegania i okazywania grzeczności.

Taka sytuacja jest bardzo prawdopodobna w kontaktach Polaków z Khmerami. Różnice kulturowe dzielące oba narody są ogromne. Konsekwencją tych różnic jest duża odmienność zachowań składających się na polski i khmerski savoir vivre.

Będąc Khmerką, która jest silnie związana i z Kambodżą, i z Polską, za rodzaj osobistej misji uważam wyposażanie Polaków w taki zasób wiedzy, by ci spośród nich, którzy zechcą posługiwać się językiem khmerskim, byli spostrzegani w Kambodży jako ludzie grzeczni.

Grzeczni - to znaczy jacy? Czym jest grzeczność? Jak ją rozumieją Polacy i Khmerowie? Jaką definicję grzeczności przyjąć, by można było skutecznie realizować - posłużę się określeniem używanym przez pedagogów - „program przysposobienia do życia w kulturze khmerskiej”?

Jako etnolingwistka i lektorka języka khmerskiego jestem przede wszystkim zainteresowana językowymi formami wyrażania grzeczności. Przybliżanie Polakom khmerskiej grzeczności językowej i stworzenie warunków do wspólnej, polsko-khmerskiej refleksji naukowej nad językowym savoir vivre Khmerów wymaga uzgodnienia pewnych definicyjnych kwestii. Właśnie potrzeba operowania jasnymi, możliwymi do zaakceptowania dla obu stron, pojęciami legła u podstaw napisania niniejszego artykułu. Jest on próbą znalezienia podwójnego kompromisu: naukowego i międzykulturowego. 


\section{Grzeczność jako element „kolektywnego zaprogramowania umysłu"}

Wyraz grzeczny jest jednym z pierwszych słów, które poznaje polskie dziecko. Poznaje jego doniosłość dużo wcześniej niż jest w stanie je wymówić. Bądź grzeczny, zjedz jeszcze trochę kaszki. Bądź grzeczna, nie zdejmuj czapki! Grzeczne dziecko! - tak matki zwracają się do nawet bardzo małych pociech. Maluch nie potrafi jeszcze chodzić, mówi tylko pojedyncze wyrazy, z jego reakcji wynika jednak, iż przeczuwa, że bycie grzecznym to coś, czego dorośli od niego oczekują. Na tym etapie życia bycie grzecznym oznacza przede wszystkim stosowanie się do poleceń rodziców oraz osób asystujących im w pełnieniu opiekuńczych funkcji. Dziecko przekonuje się, że nawet wtedy, kiedy nakazy i zakazy opiekunów są dla niego uciążliwe, posłuszeństwo jest sposobem na unikanie konfliktów z dorosłymi. Więcej - podporządkowanie się woli opiekunów często pozwala maluchowi cieszyć się miłymi oznakami akceptacji i uznania. Takie wąskie rozumienie grzeczności utrzymuje się dość długo. Z upływem czasu zwiększa się krąg osób, które mówią młodemu człowiekowi, co i jak należy robić oraz czego robić nie wolno. Zmienia się także charakter i zakres wymagań stawianych młodej osobie.

Choć dziecku często może wydawać się inaczej, nakazy i zakazy ustanawiane przez dorosłych rzadko są wytworem ich chwilowego „widzimisię". Wymagania narzucane dzieciom wynikają zazwyczaj z przekonania ich opiekunów i wychowawców, iż należy podporządkować się pewnym zasadom. Dorośli chcą „dopasować” dziecko do przyrodniczego i społecznego świata $\mathrm{w}$ sposób, który $\mathrm{w}$ ich otoczeniu jest uważany za właściwy. Zasady narzucane dzieciom mają związek - posłużę się terminologią Geerta Hofstede - z „zaprogramowaniem umysłu” dorosłych, tj. z przyswojonym przez nich $\mathrm{w}$ ciągu życia sposobem myślenia, odczuwania i zachowania1. Dorośli chcą, by myśleniem, odczuwaniem i zachowaniem dzieci sterowały te same kody, które sterują umysłami większości osób żyjących w ich społecznym otoczeniu. To wspólne ludziom żyjącym w danym środowisku społecznym „zaprogramowanie umysłu” Geert Hofstede nazywa kultura. Kultura „jest kolektywnym zaprogramowaniem umysłu, które odróżnia członków jednej grupy lub kategorii ludzi od drugiej ${ }^{2}$."

W przypadku języka polskiego, wyraz grzeczny stawiany jest obok rzeczownika kultura i pochodzącego od niego przymiotnika kulturalny niemal automatycznie. Gdy jest mowa o dziecku, grzeczność zwykle bywa rozumiana jako wypełnianie nakazów oraz przestrzeganie zakazów ważnych w społecznym współżyciu. Człowiek dorosły też jest zobowiązany do przestrzegania społecznych nakazów i zakazów, jednak jego grzeczność bywa utożsamiana przede wszystkim $\mathrm{z}$ umiejętnością kulturalnego zachowania się. Grzeczność człowieka dorosłego to grzeczność osoby,

1 (Hofstede 2000: 208-209)

2 (Tamże: 40) 
która potrafi zachować się kulturalnie. Mniej akcentowana jest w tym momencie rola posłuszeństwa, więcej świadomości i wiedzy. Człowiek zachowujący się kulturalnie to ktoś, kto wie, jak należy postępować, by być spostrzeganym jako osoba miła, uprzejma, układna. To człowiek, który tego określenia używa się rzadziej - przestrzega kulturowych norm.

Przymiotnik grzeczny jest często zastępowany przymiotnikami miły, uprzejmy, układny, taktowny. Słowa te są używane dla oznaczenia pozytywnego stosunku człowieka do otaczających go ludzi. Wyrażają aprobatę dla postawy jednostki, ale nie akcentują - jak to ma miejsce, gdy mówimy człowiek kulturalny - obecności w ludzkim zachowaniu pierwiastka kompetencji. Pierwiastek ten występuje, gdy przymiotnik grzeczny utożsamiany jest z określeniem dobrze wychowany.

Powyższe, potoczne rozumienie słów związanych $\mathrm{z}$ kategorią grzeczności jest wystarczające tak długo, jak długo nie jest potrzebna naukowa refleksja. Gdy grzecznością zaczynają zajmować się naukowcy, pospolity zdrowy rozsądek nie wystarczy - niezbędny jest metodologiczny porządek. Warunkiem zachowania tego porządku jest przede wszystkim terminologiczna spójność oraz konieczność określenia perspektywy badawczej, z której grzeczność ma być poddana naukowemu oglądowi. Etnolingwista musi, z jednej strony, przyjąć perspektywę, która odwołuje się do ogólnych ustaleń antropologii kulturowej, z drugiej natomiast ma obowiązek zastosowania perspektywy uwzględniającej specyfikę nauk zajmujących się badaniem językowych form wyrażania grzeczności.

W „Słowniku języka polskiego” pod red. Mieczysława, Szymczaka przy haśle grzeczność można przeczytać: „taktowny, delikatny, świadczący o dobrym wychowaniu stosunek do ludzi; uprzejmość; także: posłuszne, spokojne zachowanie się dziecka”, oraz: „słowa, gesty, formy zachowania się będące wyrazem uprzejmości, oznaką dobrego wychowania"3. „Odpowiedź na pytanie, co to jest grzeczność, będzie miała charakter nie tyle definicji, co raczej opisu działania, w tym także językowego" - uważa Eugeniusz Tomiczek4.

We wspomnianym słowniku przy haśle wychowanie znajduje się uwaga: „całokształt zabiegów mających na celu ukształtowanie człowieka pod względem fizycznym, moralnym i umysłowym oraz przygotowanie go do życia $\mathrm{w}$ społeczeństwie" ${ }_{5}$. Patrząc $\mathrm{z}$ perspektywy antropologa kulturowego, wychowanie można najkrócej ująć jako przekazywanie wzorów kultury.

W refleksji nad grzecznością, nie wyłączając tego jej aspektu, który dotyczy zachowań językowych, nie sposób nie odnieść się do tak ważnych pojęć, jak kultura i wzór kulturowy. Jest to niezwykle trudne zadanie. Trudne z dwóch zasadniczych powodów: po pierwsze - ze względu na

\footnotetext{
3 (Szymczak 1982: 709)

4 (Tomiczek 1992: 17)

5 (Szymczak: 786)
} 
olbrzymie bogactwo definicji kultury6. Poświęcenie satysfakcjonującej uwagi najważniejszym $\mathrm{z}$ nich wiązałoby się $\mathrm{z}$ koniecznością napisania odrębnej, bardzo obszernej pracy. Celem niniejszej tego artykułu jest odniesienie się do najważniejszych pojęć przydatnych $\mathrm{w}$ nauczaniu i badaniu khmerskiej grzeczności językowej, a nie omówienie metodologicznych ustaleń leżących u podstaw przyjęcia takiej czy innej definicji kultury. Po drugie - oddanie się szczegółowym rozważaniom dotyczącym statusu pojęć takich jak kultura i wzór kulturowy grozi uwikłaniem się $\mathrm{w}$ metodologiczne spory toczone przez przedstawicieli różnych antropologicznych szkół i kierunków. Nie chodzi o to, by w ogóle nie zajmować stanowiska, lecz o to, by przyjąć postawę otwartą na dorobek różnych środowisk naukowych. Bardzo często ich przedstawiciele skupiają się na naukowej rywalizacji, tymczasem formułowane przez nich definicje nie zawsze różnią się aż tak mocno, by można o nich było powiedzieć, iż się wykluczają. Więcej - często są to definicje, które wzajemnie się uzupełniają, gdyż albo kierują uwagę na nowe problemy badawcze, albo pozwalają ująć te same zjawiska z innej, równie interesującej, perspektywy.

Badacz zajmujący się analizowaniem językowego savoir vivre'u ma obowiązek wskazać, na jakiej koncepcji kultury się opiera. Ujęcie kultury jako „kolektywnego zaprogramowania umysłu, które odróżnia członków jednej grupy lub kategorii ludzi od drugiej” wydaje się mieć głębokie uzasadnienie, - mimo iż nie jest to ujęcie wypracowane $\mathrm{z}$ myślą o środowisku trudniącym się badaniem zachowań językowych. Koncepcja Geerta Hofstede ma wiele zalet. Jest prosta i zarazem oryginalna, gdyż opiera się na mechanizmie rozumowania przemawiającym do wyobraźni nie tylko antropologa i etnolingwisty, lecz również do doświadczenia osoby patrzącej na kulturę bez naukowych ambicji, szukającej nieskomplikowanych wyjaśnień i oczekującej posługiwania się językiem bliskim językowi potocznemu. Olbrzymią zaletą definicji Geerta Hofstede jest jej wysoki poziom ogólności. Jest to definicja bardzo pojemna, a to oznacza, iż są ją w stanie zaakceptować przedstawiciele różnych środowisk naukowych. To bardzo ważne, jeśli naukową rywalizację, przybierającą nieraz formę konfrontacji, chce się zastąpić zaproszeniem do wspólnej refleksji nad kulturą.

Jeśli przyjąć, iż kultura jest „kolektywnym zaprogramowaniem umysłu”, zaś „zaprogramowanie umysłu” to sposób myślenia, odczuwania i zachowania przyswojony przez jednostkę $\mathrm{w}$ ciągu jej życia, wzorem kulturowym będzie taka umysłowa lub fizyczna reakcja jednostki na określoną sytuację, która spełnia oczekiwania osób żyjących w danym

6 Pisząc o bogactwie i wieloznaczności pojęcia kultura, Przemysław Kisiel wymienia pracę Alfreda L. Kroebera i Clyde'a Klucholma (Culture: A Critical Review of Concept and Definitions, Peabody Museum of American Archeology and Ethnology Papers, vol. 47, nr 1, Cambridge 1952), którzy znaleźli 168 różnych definicji kultury. Już ta liczba robi imponujące wrażenie, a przecież od czasu opublikowania pracy wspomnianych autorów pojawiło się wiele nowych definicji kultury. O relacjach łączących pojęcia: kultura - wzór kulturowy - etykieta językowa zob. (Kisiel 1992: 9-14) 
środowisku społecznym. Będzie to reakcja uważana za pożądaną i ważną tak dla jednostki, jak i jej społecznego otoczenia.

Rozpoczęłam ten rozdział uwagami na temat potocznego rozumienia przez Polaków wyrazów grzeczny i grzeczność. Chciałabym go zakończyć prezentacją khmerskich odpowiedników tych słów wraz z krótkim wyjaśnieniem ich semantycznego podłoża.

Kiedy khmerski maluch zachowuje się zgodnie z oczekiwaniami matki, np. zjadł kolejną łyżkę ryżowego kleiku, albo wreszcie przestał ściągać nakrycie głowy chroniące go przed palącym słońcem, może usłyszeć

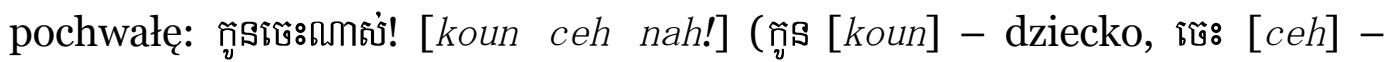
umieć, ณภาญ่ [nah] - partykuła wzmacniająca). Dziecko umie! - Wykrzykuje ucieszona matka. Co umie dziecko? O jaką umiejętność chodzi? Radość matki może być spowodowana odkryciem u dziecka konkretnej zdolności. Może jednak być tak, iż matka cieszy się po prostu, iż dziecko umie dostosować się do jej zaleceń. Cieszy się, że dziecko potrafi być posłuszne. Obecność w zachowaniu jednostki elementu posłuszeństwa to jeszcze nie grzeczność, bycie posłusznym przybliża jednak do tego, co ma związek z khmerskim rozumieniem grzeczności. Otóż khmerska grzeczność występuje tam, gdzie człowiek posłusznie dostosowuje się do obowiązujących w społeczeństwie norm i gdzie efektem dostosowania się do społecznych norm jest pozytywny odbiór jednostki przez otaczających ją ludzi. Jeśli normą jest okazywanie szacunku starszym, człowiek, który tak

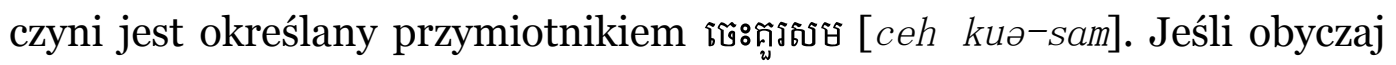
nakazuje podjęcie $\mathrm{w}$ określonej sytuacji takiego a nie innego działania językowego, człowiek, który posługuje się wzorcami językowymi umożliwiającymi okazywanie szacunku rozmówcy jest określany przymiotnikiem [ceh kuə-sam]. To bardzo ważne słowo. Jego drugi człon กู่วิธิย $\left[k u{ }^{-}-S a m\right]$ - rozpatrywany jako samodzielny leksem znaczy dosłownie być odpowiednim. [ceh kuə-sam] to khmerski równoważnik polskiego przymiotnika grzeczny. Człowiekiem grzecznym jest zatem w mniemaniu Khmerów ten, kto umie się odpowiednio zachować. Odpowiednie jest oczywiście takie zachowanie, które jest zgodne z wzorcami kulturowymi wyuczonymi i akceptowanymi przez Khmerów. Obowiązkiem każdego

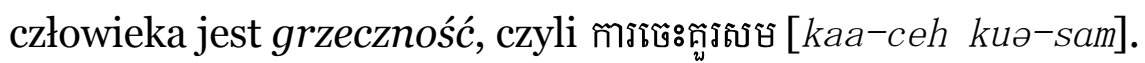

Sposób, w jaki ludzie okazują grzeczność ma związek z "kolektywnym zaprogramowaniem" ich umysłu. "Kolektywne zaprogramowanie" umysłu Khmerów jest odmienne od polskiego, odmienny jest zatem sposób, w jaki wyrażają grzeczność mieszkańcy Polski i Kambodży. Choć formy wyrażania grzeczności są w wielu sytuacjach bardzo różne, dzięki oryginalnej koncepcji Geerta Hofstede analizowanie różnic w zachowaniach grzecznościowych Polaków i Khmerów staje się łatwiejsze. Ujęcie kultury zaproponowane przez holenderskiego antropologa zbliża do siebie polskie i khmerskie rozumienie grzeczności. Okazuje się, iż na 
gruncie języka potocznego rozumienie to jest u obu narodów zadziwiająco podobne. Grzeczność jest silnie kojarzona z posłuszeństwem, dobrym wychowaniem, umiejętnością odpowiedniego zachowania się. Koncepcja Geerta Hofstede zbliża również do siebie przedstawicieli różnych szkół naukowych. Jego niezwykle pojemna definicja kultury daje im możliwość operowania wspólną perspektywą. Uwzględniając mocne zafascynowanie holenderskiego badacza kultur silnym wpływem informatycznych technologii na życie ludzi, można powiedzieć, iż dzięki jego definicji uczeni zyskują możliwość posługiwania się wspólnym „systemem operacyjnym”. Dochodzi do prostego, "kolektywnego zaprogramowania" naukowych umysłów trudniących się badaniem grzeczności. Umysłów, które gdyby trzymały się sztywno dużo węższych definicji kultury, mogłyby być ze sobą „niekompatybilne”...

\section{Etykieta językowa i honoryfikatywność}

Ustosunkowanie się do elementarnych pojęć antropologii kulturowej takich jak kultura, wzór kulturowy, wychowanie, jest niezbędne dla poczynienia definicyjnych uzgodnień przydatnych w naukowej refleksji nad tą grupą zachowań grzecznościowych, które są interesujące dla etnolingwisty - aktów grzeczności językowej.

W świetle wcześniejszych ustaleń definicyjnych, niezwykle przydatne w nauczaniu i badaniu grzeczności językowej Khmerów jest pojęcie etykiety językowej, zaproponowane przez Małgorzatę Marcjanik. Etykieta językowa jest zbiór przyjętych w danej społeczności wzorów językowych zachowań grzecznościowych, zwyczajowo przyporządkowanych określonym sytuacjom pragmatycznym7." Za grzeczne Małgorzata Marcjanik uważa te zachowania językowe, których w danej sytuacji zaniechać nie wypada8. Stanowisko definicyjne Małgorzaty Marcjanik, reprezentującej dział językoznawstwa pragmatycznego, okazuje się być bardzo bliskie khmerskiemu rozumieniu grzeczności, ujmowanej jako umiejętność odpowiedniego zachowania się w określonej sytuacji. Użytkownikowi języka khmerskiego stanowisko to kojarzy się od razu z określeniem [kaa-ceh kuə-sam].

Pojęcie etykiety językowej i sposób jej badania jest przedmiotem ożywionych polemik w gronie językoznawców oraz etno- i socjolingwistów. Tak jak uznałam, iż próba bliższego przyjrzenia się naturze polemik poświęconych rozumieniu kultury wiązałaby się z koniecznością zajęcia się niezwykle złożonym problemem naukowym, trudnym do opisania w skromnych ramach jednego artykułu, tak samo chcę uniknąć głębszego angażowania się $\mathrm{w}$ spory metodologiczne związane $\mathrm{z}$ zagadnieniem grzeczności językowej. Pojęcia, które w powszechnym mniemaniu uchodzą za oczywiste, w naukowej dyskusji traktowane są często jako wieloznaczne i z tego powodu bardzo skomplikowane.

7 (Marcjanik 2007: 12)

8 (Tamże: 8) 
Oparcie się w badaniu i nauczaniu khmerskiej grzeczności językowej na definicji etykiety językowej Małgorzaty Marcjanik uzasadniam dwoma prostymi względami: obecnością wspomnianej definicji $\mathrm{w}$ wielu publikacjach poświęconych polskiej grzeczności językowej oraz potrzebą sprostania najczęściej wyrażanym oczekiwaniom poznawczym polskich adeptów języka khmerskiego.

Wielu uczestników kursu języka khmerskiego, chcąc mieć odczucie szybkiego postępu $\mathrm{w}$ nauce, chciałoby $\mathrm{w}$ krótkim czasie poznać jak najwięcej szablonów językowych pełniących funkcję wyrażeń grzecznościowych. Pragną skonfrontować polskie tzw. autonomiczne akty grzeczności z ich khmerskimi odpowiednikami. Autonomiczne akty grzeczności oznaczają wyrażenia językowe, które "orzekają o relacjach wyłącznie grzecznościowych między partnerami interakcji werbalnych"9. Chodzi o utrwalone tradycją akty mowy, mające postać szablonów, które użytkownicy języka bez trudu rozpoznają i jednoznacznie nazywają, np. powitania, podziękowania, przeproszenia, życzenia itp. Tam, gdzie kontekst sytuacyjny jest jednakowo czytelny dla Polaków i Khmerów, zastąpienie polskich szablonów językowych w funkcji grzecznościowej ich khmerskimi odpowiednikami jest proste - wystarczą nieskomplikowane zabiegi translacyjne. Nie brakuje jednak okoliczności, w których polska perspektywa jest bardzo odmienna od khmerskiej. W takich przypadkach znajomość khmerskich szablonów językowych będzie potwierdzeniem zdolności uczestnika kursu do poprawnego słownikowo i gramatycznie posługiwania się pewnymi wyrażeniami, może jednak nie wystarczyć do tego, by dać przekonujący dowód posiadania kompetencji kulturowej. Zamiar zademonstrowania grzeczności językowej może zostać niezrealizowany albo zrealizowany w stopniu niewystarczającym.

Pragnienie, by nauczanie językowego savoir vivre’u Khmerów nie zostało zawężone do przedstawienia skonwencjonalizowanych zachowań werbalnych w funkcji grzecznościowej nakazuje uwzględnić bardzo przydatną poznawczo koncepcję Romualda Huszczy, który przy opisie zjawisk związanych z szeroko pojmowaną grzecznością językową posługuje się kategorią honoryfikatywności. Wspomniany znawca języków wschodnioazjatyckich definiuje honoryfikatywność jako „pewien szczególny rodzaj znaczenia zawartego w treści wypowiedzi, a mianowicie jako informację o towarzysko-społecznej relacji między nadawcą a odbiorcą, relacji między nadawcą a słuchaczem niebędącym bezpośrednim odbiorcą (adresatem wypowiedzi), oraz relacji między nadawcą a bohaterem wypowiedzi ${ }^{10}$." Romuald Huszcza zwraca uwagę, iż zachowania językowe, które w językoznawstwie pragmatycznym określane są jako autonomiczne akty grzeczności albo behawitywy różnią się pod względem nacechowania honoryfikatywnego ${ }^{11}$. Bardzo często nie wystarcza samo stwierdzenie, iż pewne wypowiedzi są w określonej sytuacji

9 (Marcjanik 1992: 30)

10 (Huszcza 2006: 47)

11 (Tamże: 179) 
komunikacyjnej stosowne. Potrzebna jest jeszcze ocena, które z dwóch lub więcej zachowań językowych spełniających kryterium stosowności najbardziej adekwatnie wyrazi charakter towarzysko-społecznej relacji łączącej nadawcę $\mathrm{z}$ odbiorcą bezpośrednim i pośrednim oraz nadawcę $\mathrm{i}$ bohatera wypowiedzi. Przy formułowaniu takiej oceny kategoria honoryfikatywności jest niezwykle pomocna. Honoryfikatywność jest pojęciem bardzo blisko związanym z etykietą językową, nie należy jednak obu tych pojęć utożsamiać.

Bez odwoływania się do kategorii honoryfikatywności trudno jest wyjaśnić niuanse związane $\mathrm{z}$ funkcjonowaniem khmerskiego systemu adresatywnego. Jego złożoność i duża odmienność od systemu polskiego sprawia dużą trudność osobom podejmującym się studiowania języka khmerskiego. Polak, który pragnie być spostrzegany w Kambodży jako człowiek grzeczny, nie ma trudnego zadania. Khmerowie są w stosunku do obcokrajowców niezwykle pobłażliwi, pozwalając im stosować mocno uproszczoną wersją systemu adresatywnego. Polakowi będzie się ona kojarzyła z pozostawaniem w relacji na pan/pani lub na ty. Kto jednak ma silne potrzeby poznawcze i pragnie uzyskać informacje o statusie społecznym komunikujących się ze sobą Khmerów oraz poznać naturę lączących ich emocjonalnych więzi, bez kategorii honoryfikatywności obyć się nie może. Jest ona narzędziem pomocnym w korzystaniu z bogactwa khmerskich form adresatywnych.

\section{Podsumowanie}

Ucząc Polaków języka khmerskiego i przygotowując ich do sprawnego poruszania się $\mathrm{w}$ kulturze khmerskiej, należy podkreślać potrzebę „przeprogramowania” ich umysłu, by był on „kompatybilny” z umysłem mieszkańców Kambodży. Bardzo ważne jest, by komunikujący się po khmersku Polak był w stanie, gdy zajdzie potrzeba, wyjść poza ramy narzucone mu przez nawyk posługiwania się polskimi wzorami kulturowymi. Oczywiście nie jest to latwe, ale warto jest podjąć ten trud. Chodzi nie tylko o emocjonalną gratyfikację wynikającą z konstatacji, iż żyjąc w obcej kulturze jest się spostrzeganym jako człowiek grzeczny. Otwarcie się na inną kulturę to - posłużę się jeszcze raz oryginalnym porównaniem Geerta Hofstede - sposobność opanowania nowego „systemu operacyjnego”. A to oznacza pozyskanie nowych, interesujących możliwości... 


\section{Bibliografia}

Hofstede, G. 2000. Kultury i organizacje. Zaprogramowanie umystu. Tłum. Durska, M. Warszawa: Polskie Wydawnictwo Ekonomiczne.

Huszcza, R. 2006. Honoryfikatywność. Gramatyka. Pragmatyka. Typologia. Warszawa: Wydawnictwo Naukowe PWN.

Kisiel, P. 1992. Etykieta językowa a wzory kultury. w: Anusiewicz, J., Marcjanik, M. (red.) Język a kultura, t. 6: Polska etykieta językowa. Wrocław: Wiedza o Kulturze.

Marcjanik, M. 2007. Grzeczność $w$ komunikacji językowej. Warszawa: Wydawnictwo Naukowe PWN.

Marcjanik, M. 1992. Typologia polskich wyrażeń językowych o funkcji grzecznościowej, w: Anusiewicz, J., Marcjanik, M. (red.) Język a kultura, t. 6: Polska etykieta językowa. Wrocław: Wiedza o Kulturze.

Szymczak, M. (red). 1982. Stownik języka polskiego. tom 1. Warszawa: Państwowe Wydawnictwo Naukowe.

Tomiczek, E. 1992. Z badań nad istota grzeczności językowej. w: Anusiewicz, J., Marcjanik, M. (red.) Język a kultura, t. 6: Polska etykieta językowa. Wrocław: Wiedza o Kulturze. 